\title{
The Impact of a Teacher Preparation Programs on Professional Teaching Competencies - Female Novice Teachers' Perspectives
}

\author{
Saba Qadhi, Manal Hendawi, Elham Ghazi Mohammad, Intisar Ghazi, \\ Nasser Al-Dosari and Xiangyun Du \\ Qatar University \\ Doha, Qatar
}

\begin{abstract}
This study explored early career teachers' perspectives on their competencies in professional teaching in Qatar. Using a mixedmethod research design, this study drew on empirical data from ninetlyfive survey respondents and ten individual interviews with teachers who were in their first four years of working in Qatari governmental schools. The findings of this study indicate that professional teaching competencies are strongly related to professional training through a teacher preparation program. This study identified a few of the specific challenges that novice teachers encounter and revealed a significant need to address these challenges to maintain their competencies. The study contributes to the literature by investigating novice teachers' perspectives on their teaching competencies as supported by their teacher preparation program. More efforts to bridge the gaps between programs and schools are needed to prepare teachers in their early careers better.
\end{abstract}

Keywords: novice teachers; professional competence; training programs; preparation program; Qatar

\section{Introduction}

Student teachers are challenged to develop the professional teaching competencies needed to demonstrate high-level skills while preparing to work in schools. An alarming number of novice teachers do not fully make this transition after they complete their training, but rather leave the teaching profession in their first years of work. This can be explained by a lack of induction plans and professional development designed for new teachers (Fantilli \& McDougall, 2009). The study will be significant as it can be used to redesign the teaching program at the university and implement an induction plan in the schools to benefit the students more and, in return, improve the overall education quality in the country. Novice teachers play a critical part in the country's education system, and their actions significantly influence the state of the education system 
in the country. Graduates from Qatar University's teaching program are expected to be ready to discharge their duties immediately.

This research described some of the specific challenges that novice teachers face and showed a clear need to tackle these challenges to improve their skills and competencies. The research adds to the literature by exploring the experiences of novice teachers regarding their teaching skills as guided by their teacher training program. Further efforts are needed to bridge the gaps between programs and schools to better prepare teachers for early careers.

One of the most important reasons has been that novice teachers lack confidence in their capabilities and competencies to manage teaching work in practice (Baecher, 2012). Previous studies have identified a considerable lack of selfefficacy and presence of anxiety among novice teachers, and their first years of practice are regarded as a time of critical development (Faez \& Valeo, 2012). When novice teachers face the reality of the profession's requirements, they either strengthen their efficacy beliefs or leave the profession (Tschannen-Moran \& Hoy, 2007). This situation has led to the debate surrounding whether the quality of pre-service programs, schools' organizational cultures, and education policies are truly enhancing teachers' competencies and helping them to keep up with the changes and workload (Cochran-Smith, 2013).

Facing global challenges, much of the recent literature has paid attention to the reasons behind many novice teachers' choice to leave their profession as well as finding potential solutions to the shortage of qualified teachers (Sutcher, Darling-Hammond, \& Carver-Thomas, 2016). Further, more recent attention has focused on the provision of adequate teaching preparation plans to help new teachers better prepare for their work (Ödalen, Brommesson, Erlingsson, Schaffer, \& Fogelgren, 2019).

While a growing body of studies emphasizes the importance of novice teachers' self-efficacy, and job satisfaction (author, 2017, 2018; Canrinus, Helms-Lorenz, Beijaard, Buitink, \& Hofman, 2012), little is known about how novice teachers perceive their competencies in managing their teaching work at an early stage in their career. Therefore, it is essential to explore how novice teachers think they have achieved the necessary skills for their teaching profession with the support of teacher preparation plans. It is also required to discuss the challenges that novice teachers have encountered in applying the skills gained through their preparation programs to their teaching training in schools.

Nevertheless, society is still facing a severe challenge in that it lacks sufficient teachers, particularly qualified teachers (Ahmed, 2018; Ellili-Cherif, Romanowski, \& Nasser, 2012). To prepare qualified teachers better, it is crucial to know how novice teachers evaluate their competencies related to their profession. Therefore, this study aims to explore how newly graduated teachers perceive their success in achieving the expected skills during their teacher preparation programs. Through a mixed-method study, we quantitatively surveyed ninety-five early career teachers' self-evaluations of their teaching 
proficiencies. Through interviews with ten teachers, we qualitatively explored their insights about how they were prepared for working as a teacher and what challenges they faced.

\section{Literature Review}

\subsection{Research on novice teachers}

According to (Rivkin, Hanushek, \& Kain, 2005), teachers have a significant impact on student learning than any other factor related to the school system. The criticality of teachers to student learning, therefore, demands that they are well trained and adequately prepared to meet the objectives of their country's education sector (Bettini, Jones, Brownell, Conroy, \& Leite, 2018; Glennie, Mason, \& Edmunds, 2016; Tait, 2008). It is, therefore, essential to understanding the preparation and retention of novice teachers, defined as those who are new entrants in the field or who have zero to three years of experience. Numerous studies have examined novice teachers' retention, retention problems, and the need to address critical issues within teacher preparation programs (Gold, 1996; Smith \& Ingersoll, 2004; Veenman, 1984; Zeichner \& Tabachnick, 1981). However, novice teachers themselves have had limited input in determining practical approaches (Bettini et al., 2018). In addition to changing policies and reform models, novice teachers are likely to leave their jobs, mainly due to a lack of administrative assistance (Holmes, Parker, \& Gibson, 2019; McLean, Abry, Taylor, Jimenez, \& Granger, 2017).

Various studies have focused on the lack of competencies among novice teachers and the challenges they face in the teaching field (Friedman \& Kass, 2002; Truchot \& Deregard, 2001). Scholars have highlighted various aspects of teacher development related to these challenges; for instance, some studies point out that insufficient knowledge of school organization generates stress, which in turn affects the performance quality of novice teachers (Brackett, Mayer, \& Warner, 2004; Lopes, Grewal, Kadis, Gall, \& Salovey, 2006). On the other hand, some researchers claim that the formation of stress that stimulates the performance of teachers is backed up by the pressure that has been inducted in them through their educational program (Gavish \& Friedman, 2010; Levski, 2003). Novice teachers may also experience particular stress because, since they are a part of an organization, they are assumed to work with the same efficiency and provide quality teaching at the same level as their senior colleagues (Brackett et al., 2004; Zins, 2004).

\subsection{The role of teacher preparation programs}

The crucial role of a preparation program is developing capabilities in novice teachers and enhancing their teaching competency (Azhar \& Kayani, 2017).

Another ongoing change in teacher preparation programs is an increased focus on self-reflection. The majority of training workshops and professional development opportunities for novice teachers now pay attention to preparation done by the teacher through self-study (Goodwin et al., 2014). Similarly, teachers are observed to pay keen attention to their routines and curriculum and 
maintain an individualistic focus to develop relative behavior (DeAngelis, Wall, \& Che, 2013; Kang \& Zinger, 2019). This focus on self-reflection is based on the idea that any teacher who lacks self-understanding cannot retrieve the behavior of students (Kukla-Acevedo (2008). Likewise, according to a stage-based model of teacher growth, novice teachers are not able to understand the thinking of students until they can recognize themselves as teachers and understand the classroom practices (DeAngelis, Wall, \& Che, 2013). Many teachers work in specialized professional contexts in which they struggle to focus their attention on the classroom routines and curriculum and also struggle to focus on their behavior concerning the thinking of the students. It is crucial to understand and address this struggle because a teacher's qualification and content exposure have a remarkable effect on their students' achievements (Kang \& Zinger, 2019). However, the practice of teacher training remains neglected due to a small number of educational institutions (Celik, 2011) and to several other factors (Youngs, Odden, \& Porter, 2003). To address this lack of adequate teacher training, researchers should investigate the gap between the stimulating filaments of teacher preparation programs and their implementation in education plans.

\subsection{Teacher education in Qatar}

Teacher education in Qatar, as in other Arab Gulf regions, is characterized by a significant proportion of foreign teachers and by a majority female workforce. The supremacy of women in education and their omission from specific fields like administration and engineering is aligned with the conventional religious limitations placed on females, and the conventionally acceptable part of females as teachers in Islamic civilization was rapidly strengthened by various influential societies in Qatar (Abu-Tineh \& Sadiq, 2018).

However, changes are underway, both in the gender balance of the teaching workforce and in the training of teaching. In 2001, the Qatari government raised concerns about the outcomes of the education system of Qatar due to the low scores obtained by secondary students in the Program for International Assessment (PISA) study and the Trends in International Mathematics and Science Study (TIMSS). The administration encouraged to embark on initiatives based on suggestions and recommendations for creating an educational system that would fulfill the changing needs of Qatar (Romanowski, Ellili-Cherif, Al Ammari, \& Al Attiya, 2013).

Since then, studies have paralleled Qatar's national focus on teacher training plans (Romanowski et al., 2013). In their detailed description of the education program and the aspects in which it lags, these studies have identified several attributes. To begin with, Qatar is now clearly inclined towards a modern form of training and development of teachers (Chaaban \& Du, 2017). In 2001, a lack of competency in teachers was found to create obstacles for the students. After the reforms that began at the turn of the century, the development of teachers in Qatar has been viewed as a useful measure in that it is assisting students to be more expressive (Nasser, Cherif, \& Romanowski, 2011). Currently, Qatar is still making crucial efforts to improve teacher development, although the traditional 
training of a pressurized work culture persists in some regions (UNESCO, 2019). Consequently, there is a need for a detailed analysis of the factors that limit the implementation of teacher preparation programs.

Our review of the related literature has established that teacher preparation programs are essential for the development of novice teachers. However, not all the available educational institutions in Qatar are still implementing such programs. The Supreme Education Council's Schools and Schooling report, which was issued in 2013, emphasized issues affecting performance in a government school; some of this one-third of independent school-teachers did not have a formal teaching qualification. Another critical point that has been identified from the literature is that teacher preparation programs are essential for the development of teachers as well as students. Also, this process yields opportunities for expert teachers to enhance their capabilities and launch new career opportunities. In response to the problems identified in the literature review, we formulate the following research questions:

1) In which ways do novice teachers think they have achieved the needed competencies for their teaching profession with the support of the teacher preparation programs?

2) What challenges have novice teachers met in applying the competencies gained through their preparation programs to their teaching practices in schools?

\section{Methods}

\subsection{Research context}

Q University is one of the leading institutions in the country, and its college of education is one of the essential institutions responsible for producing the country's teachers. It offers a total of four programs, including early childhood education and primary, secondary, and diploma programs in Arabic, English as a second language, mathematics, science, social studies, and Islamic studies. The programs include four years period of study before the undergraduates can obtain a bachelor of arts degree, and in the fourth year, students have 10-weeklong internships in schools. On average, 1,000 students (95\% female and 5\% male) attend this college, and it graduates around 300 students each year. More than half of these go on to work in governmental schools.

\subsection{Participants}

Study participants included early career teachers who completed the undergraduate program study at Qatar University and worked as teachers in governmental schools for less than four years. After receiving ethical approval from the Ministry of Education and Higher Education and the Ethical Committee of Qatar University, the University does not keep official records of the employment situation for each graduate program. Our message asked the schools to forward the email to their newly employed teachers. Ninety-five teachers responded to our survey, and of these, ten participated in the interviews. All participants in this study were female. We divided the 
participants into two groups: teachers with one year's teaching experience or less and teachers with one to three (less than four) years' teaching experience.

\subsection{Research design and data generation}

Explanatory mixed-method research was employed for data generation (Creswell \& Clark, 2017). Two phases and sources of data were included: first, a questionnaire-based survey was used to invite the novice teachers to evaluate their competencies for the teaching profession; second, individual interviews were conducted with ten novice teachers.

\subsubsection{Quantitative data sources - a questionnaire-based survey}

A questionnaire-based survey method was used to gain an overview of the opinions and standpoints of novice teachers. The questionnaire was developed by the research team to align with the curriculum objectives of the teacher preparation program and the national professional standards for teachers in Qatar (Council, 2007). The questionnaire contained ten items inviting participants to respond to the question, "Could you please reflect and report to what levels you were prepared for your teaching job in the following aspects?" using a four-point Likert-type scale.

$1=$ "Not prepared at all, and I am not competent in this aspect"

$2=$ "Reasonably prepared, and I am confident in demonstrating most of the requested competencies in this aspect"

$3=$ "Well prepared, and I am highly confident in demonstrating all requested competencies in this aspect"

$4=$ "Excellent, and I am highly confident in demonstrating excellence in this aspect"

Following (Creswell \& Clark, 2017), the questionnaire development procedure was as follows: 1) interviews were conducted with four teacher preparation program faculty members; 2) four programs coordinators reviewed an initial draft of the survey; 3) expert validation was conducted by other, senior experts with 10-20 years of experience in teacher preparation programs, followed by minor revisions regarding the phrasing of items 1, 2, 6, 8 and 9; and 4) another expert validation was conducted by statistical experts to review the rate and scale of the questionnaire design. Three rounds of discussion led to the revision of the scales before the research team, and experts reached a final agreement on the current version. After the expert validation, a language professional first performed translation into Arabic. Then back-translation was used to examine the validity and linguistic parallelism of the questionnaire (Cohen, Manion, \& Morrison, 2013). A few rounds of translation back and forth between English and Arabic were carried out before two other language experts reached a final agreement on its validity. Then the survey was tested by five novice teachers.

\subsubsection{Qualitative data sources - semi-structured interviews}

The individual interviews were conducted to firstly triangulate the quantitative data results and secondly to further explore these teachers' experiences and challenges. Ten teachers volunteered to participate in the semi-structured interviews after they had participated in the survey. Among these, six were first- 
year teacher graduates, and four had worked for between one and three years. All the volunteer teacher participants were female, with an age range of 24-30. During the interviews, they were invited to reflect on their work performance regarding their professional knowledge, overall teaching skills, and professional disposition. They were also asked to provide examples demonstrating how their teaching had led to students' learning gains. Besides, they were invited to relate their current performance at work to the teacher preparation program they had attended and to identify challenges in applying what they had learned to their work. Each interview lasted 30-60 minutes. The interviews were conducted in Arabic and audio-recorded, then transcribed and translated to English for content analysis (Kvale \& Brinkmann, 2009).

\subsubsection{Data analysis}

The quantitative data from Ninety-five surveys were analyzed based on descriptive statistics to examine participants' responses. We computed the means and standard deviations for each item of the questionnaire.

To analyze the qualitative data from the ten interviews, we employed a thematic analysis based on the interview questions and the commonalities in the responses obtained from the interviewees that, helped us to infer meanings with the help of linguistic features in the agreed settings (Cohen et al., 2013). Our analysis also focused on strengthening the meanings expressed by the interviewees, which were then coded for analysis, whereby the concepts revealed through the responses were shortened (Kvale \& Brinkmann, 2009).

\section{Results}

\subsection{Quantitative data results}

Fundamental statistical analysis was conducted on the data collected using the questionnaire. The Cronbach's alpha of the survey is .946, indicating the right scale of reliability of the measure. The means and standard deviations of each item of the survey were calculated to identify the perspectives of novice teachers. We also compared the two groups of teachers: those with one to three years of experience and those who were first-year graduates $(\mathrm{N}=17)$. The descriptive statistics for the participants' responses are presented in Table 1, providing an overview of the conclusion of the quantitative data source.

Table 1: Overview of the quantitative data analysis results

\begin{tabular}{|l|l|l|l|l|l|l|}
\hline & \multicolumn{2}{|l|}{$\begin{array}{l}\text { 1-3 years' } \\
\text { experience } \\
(\mathrm{N}=78)\end{array}$} & \multicolumn{2}{l|}{$\begin{array}{l}\text { First-year } \\
\text { graduates } \\
(\mathrm{N}=17)\end{array}$} & \multicolumn{2}{l|}{ Total (N=95) } \\
\hline Items & Mean & $\begin{array}{l}\text { Std. } \\
\text { Dev. }\end{array}$ & Mean & $\begin{array}{l}\text { Std. } \\
\text { Dev. }\end{array}$ & Mean & $\begin{array}{l}\text { Std. } \\
\text { Dev. }\end{array}$ \\
\hline $\begin{array}{l}1 . \quad \text { Providing a variety of } \\
\text { opportunities that support student } \\
\text { learning and development. }\end{array}$ & 3.14 & 0.82 & 3.41 & 0.62 & 3.19 & 0.79 \\
\hline $\begin{array}{l}2 . \quad \text { Accommodating students' } \\
\text { differences and cultural } \\
\text { backgrounds to provide them with }\end{array}$ & 3.04 & 0.89 & 3.18 & 0.73 & 3.06 & 0.86 \\
\hline
\end{tabular}




\begin{tabular}{|l|l|l|l|l|l|l|}
\begin{tabular}{|l|l|l|l|} 
learning fopportunities for \\
improving their achievements.
\end{tabular} & & & & & & \\
\hline $\begin{array}{l}\text { 3. Establishing a classroom } \\
\text { environment of respect and support } \\
\text { that provides a culture for learning. }\end{array}$ & 3.32 & 0.83 & 3.47 & 0.62 & 3.35 & 0.80 \\
\hline $\begin{array}{l}4 . \text { Having sufficient content } \\
\text { knowledge in the professional field. }\end{array}$ & 3.08 & 0.92 & 3.35 & 0.61 & 3.13 & 0.88 \\
\hline $\begin{array}{l}\text { 5. Motivating learners and engaging } \\
\text { them in critical thinking by teaching } \\
\text { a variety of perspectives and } \\
\text { concepts. }\end{array}$ & 3.13 & 0.94 & 2.94 & 0.83 & 3.09 & 0.92 \\
\hline $\begin{array}{l}\text { 6. Engaging in assessment activities } \\
\text { and using the data for instructional } \\
\text { decision making and student } \\
\text { improvement. }\end{array}$ & 3.05 & 0.88 & 2.71 & 0.77 & 2.99 & 0.87 \\
\hline $\begin{array}{l}\text { 7. Planning integrated and coherent } \\
\text { instruction to meet the learning } \\
\text { needs of all students. }\end{array}$ & 3.08 & 0.91 & 3.47 & 0.51 & 3.15 & 0.86 \\
\hline $\begin{array}{l}8 . \quad \text { Providing student-centered } \\
\text { instruction that is characterized by } \\
\text { clarity, variety, and flexibility. }\end{array}$ & 3.10 & 0.86 & 3.12 & 0.70 & 3.11 & 0.83 \\
\hline $\begin{array}{l}\text { 9. Reflecting on and using multiple } \\
\text { resources, such as professional } \\
\text { literature and interacting with } \\
\text { colleagues, to aid growth as an } \\
\text { educator. }\end{array}$ & 3.17 & 0.86 & 2.94 & 0.56 & 3.13 & 0.82 \\
\hline $\begin{array}{l}\text { 10. Collaborating to ensure learner } \\
\text { growth and advance the profession. }\end{array}$ & 3.26 & 0.81 & 3.53 & 0.51 & 3.31 & 0.77 \\
\hline Total & 3.14 & 0.74 & 3.21 & 0.39 & 3.15 & 0.69 \\
\hline
\end{tabular}

Following the scale range of 1:00-1.75 for scale 1, 1.75-2.50 for scale 2, 2.50-3.25 for scale 3, and 3.25-4.00 for scale 4, the overall result of the novice teachers' selfevaluation of their performance at work is positive, with a total mean of 3.15 for the whole survey. That means the participants believed they were prepared for their teaching position. Comparing the two groups, teachers with one to three years' experience reported $M=3.21$ for all items, while teachers with less than one year's experience reported $M=3.14$ for seven out of the ten items. Although there were three items with means of lower than three reported by teachers with less than one year's experience, they were still within the range of scale 2, meaning they considered themselves generally prepared.

A t-test was conducted to compare the two groups (one to three years of experience and first-year graduates), and no significant difference was identified between them, either for any of the individual items or for the ten items in total $(\mathrm{t}=-0.41)$.

\subsection{Qualitative data results}

The ten interviewees confidently self-evaluated their readiness for working as teachers in the aspects of professional knowledge, teaching skills, and professional dispositions. During the analysis, attention was paid to the comparison between those teachers in their first year of teaching experience (T1- 
6) and those with one to three years' experience (T7-10). Similar to the quantitative results, there was no apparent difference between the two groups of participants. Nevertheless, more individualized opinions were observed regarding different aspects of teacher readiness. Below, we report the interview findings in the following structure: 1) teaching performance and its impacts on student learning gains; 2) link between teaching performance and the teacher preparation program; 3) points missing from the teacher preparation program, and,; 4) teaching-learning through work.

\subsubsection{Teaching performance and its impacts on student learning gains}

All the teacher participants discussed how their teaching performance contributed to student learning gains. Interestingly, the participants provided contrary evidence in this matter. Four of them (T3, 5, 7, and 9) considered helping students by using diverse teaching strategies to be one of their teaching achievements. As one participant said:

I apply a lot of teaching strategies and methods. I also take into account individual differences. I use different visualization strategies, some students are visual, auditory, and some like hand-on experiences. Therefore, I use all of that to deliver information and to improve the students' performances. (T5)

Some teachers $(T 4,6,8,10)$ referenced increased scores as good evidence of their performance and achievement:

I believe the best way to see my teaching outcomes are to prove that students improve their scores. In the past three years, I think my students have made excellent achievements in their grades. (T8)

The two teachers (T1 and 2) working in the area of early childhood education observed student growth as an achievement in both their teaching and their learning:

I have only been here for a month, and I have not managed a class yet. However, I tried to help the shy students who never speak to participate, and interact. A student never spoke when I first got here, but now she does, and she is more social now. (T1)

\subsubsection{The link between teaching performance and the teacher preparation program}

The interviewed teachers were generally satisfied with what they learned from the teacher preparation program. They could link the benefits; they gained from the program to their daily exercise of teaching. The most cited benefits of the program included theories that helped develop a conceptual understanding of teaching and learning, a wide range of teaching strategies and skills for classroom management, and opportunities for micro-teaching. As they expressed:

I am glad I was in that program, and it made a significant influence on me. It made me feel confident at work.... I am used to creating new 
teaching strategies... I can see I know quite a lot of strategies that even qualified teachers do not know. (T3)

It (the university program) had a significant influence in the sense that I proficient the situations that I now experience with my students. The experience of managing a class during the internship was highly beneficial, and the university instructors were role models for me at work. (T4)

I have been teaching two and a half years now, and people in my school always say that they chose me because I graduated from the Qatar university program, meaning I am high-quality. Moreover, I have proved this to them. This made me quite proud of my program of study.

Nevertheless, T7 pointed out that the quality of teaching was also related to individual factors, including attributes such as responsibility and passion. As she said:

I think being a teacher is not about being a graduate from any college. It has more to do with our passion and how we love the profession of teaching. With passion, we can get more engaged in the job and with our students. Without passion, even graduates of the best program may not necessarily make a good teacher.... [It] depends on the individual. (T7)

\subsubsection{Challenges - Points missing from the teacher preparation program}

The interviewed teachers identified a few significant challenges, which were described as points missing from their teacher preparation program. First, all the teachers interviewed mentioned that, despite their confidence in their professional knowledge and skills, during their first six months, they experienced a gap between the program and their work-life, and sometimes they felt insecure about how to handle specific real-life situations. As one of them said:

I know the teaching strategies, and I know when to use each strategy. However, my problem is that sometimes I do not know what to do in specific situations. For example, I took the Child Development course, but now I deal with children who are three years old. I cannot give them academic stuff because they should only learn some letters and pronunciation. The strategies that I learned are not very helpful in this situation. (T2)

Besides, half of the interviewed teachers reported knowledge gaps regarding assessment. The quantitative outcomes reflect where the survey question regarding assessment yielded the lowest of all scores from first-year graduates (2.71) during their teacher preparation.

In our program, we had a course on assessment, which gave us many techniques for how to assess students; I even got a good grade in that 
course. Nerveless, I never learned how to deal with all the issues around assessment in real life. We are only testing students on memorization because we only want good grades. Now I am learning how to use assessment to provide feedback and consider this process qualitatively rather than quantitatively. (T7)

Further, three teachers $(\mathrm{T} 2,5,9)$ mentioned their lack of preparation for handling students in a classroom setting. As one said:

I know a lot about the theories of classroom strategies, but I wish I had known more how to deal with students; in particular, they are so different from each other. I did not know until I was standing in the classroom. It took me two years of struggling with this, and I may have gotten more confident now, but I still have a lot more to learn. (T9)

\subsubsection{Teacher learning}

All the interviewed teachers expressed positive attitudes about their ongoing learning while working as a teacher and in particular about applying what they learned in their university programs to real-life training. As one teacher said:

We must continue to learn new things. Although we learned a lot from the university program, it was not enough for me. I still have to learn some things. (T1)

Also, three teachers $(\mathrm{T} 4,7,9)$ reflected on the effect of real-world experience. As one said:

What I learned from the program is meaningful now based on the work experience. The teaching experience makes me learn more comprehensively. (T4)

The interviews also identified one missing aspect of teacher preparation, which is that some interviewees struggled with continuous learning in response to reallife problems. As one said:

When I face situations where I do not know what to do, I am now reading books to search for answers... (T6).

\section{Discussion}

This study aimed to explore novice teachers' self-evaluation of their competencies at work. A mixed-method design was used, including quantitative data from the survey findings of ninety-five teachers and qualitative data from interviews with 10 participants.

\subsection{Novice teachers' perception of their teaching competency}

We attempted to evaluate the perceptions of teachers regarding their teaching competencies with the support of teacher preparation programs. Based on the quantitative assessment, we inferred that the teachers were generally confident in their abilities to apply the professional knowledge, skills, and dispositions 
targeted by their preparation programs during their work in Qatari governmental schools. This is also consistent with the conclusion of the qualitative analysis, in which all participants confidently evaluated themselves as being ready to perform the part of a teacher in the areas of teaching skills, professional knowledge, and professional disposition. It is noteworthy that these results contradict the findings of (Goh, Yusuf, \& Wong, 2017), who found that there is significant variation among novice teachers regarding their perceptions of their competencies and that these perceptions are subject to different situations and the quality of teaching preparation program.

The researchers conducted a study on two groups of teachers by drawing a comparison between teachers with less than one year of experience and teachers with one to three years of experience. No differences were found between these two groups in terms of their perception of their teaching skills following the outcomes of the qualitative analysis. Similarly, the outcomes of the t-test in the quantitative analysis also found no differences in the perceptions of the two groups, as all participants were confident in their readiness to teach.

The results of this study also indicated that certain aspects of teacher preparation programs need to be improved; for example, participants reported in the survey that they had the least confidence in their preparation for student assessment, which is in line with conclusion reported in previous studies (Alkharusi, 2011). This result suggests a gap between the theories teachers learn in their teacher preparation programs and the practice of teaching in schools, and it more explicitly suggests explicitly that assessment theory is far from the real practice of diverse assessment methods. This aspect deserves more attention in teacher preparation programs in terms of providing student teachers with more chances to understand the reality of work-life in schools regarding developing diverse assessment techniques and, in particular, using assessment as a way to encourage student learning. The results of the interview corroborated the quantitative results, further revealed the concern of the participants about developing evaluation methods that promote student learning, and highlighted evaluation techniques as a critical issue among novice teachers, who consider the grades and scores of the students to be the only way to assess their performance. While the evaluation is already recognized as important teaching ability, one suggestion for teacher training programs would be to further improve the effectiveness of teachers in evaluating students in a manner that helps them achieve their maximum potential.

Also, it is worth pointing out that the novice teachers in this study reported a comparatively low level of reflection that drew on multiple resources, such as literature or peer comments. In Qatar, although classroom study and collaborative learning are encouraged, these practices remain limited (Al-Kaabi \& Hossain, 2018). Collaboration learning, peer review, and assessment are approved in the classroom to increase the students' reflections in the teaching and learning process.

It suggests that teacher-training programs should further improve the skills of classroom study and collaborative learning with colleagues. Furthermore, the 
qualitative data revealed the impact of teaching performance on student learning gains, with a variety of evidence provided by the participant teachers. Some of the teachers in this context identified the positive impact of their teaching on student performance based on the scores and grades of the students. However, some of the teachers provided evidence of a positive teaching impact on student performance based on students' interpersonal skills development. In this regard, one of the respondents found improvement in students' speaking skills after the end of the year. This is validated by the work of (Adnot, Dee, Katz, \& Wyckoff, 2017), who found that effective teaching performance tends to have a significant impact on students' interpersonal skills, as effective teachers increase student confidence and enable them to develop these skills to their full potential. It means that teacher-training services already provide student teachers with specific opportunities to improve their communication skills for student teachers to enhance their communication, interpersonal, and teamwork skills so that they can better use those skills to facilitate learning for their students. Moreover, the results of the interviews outline a visualized strategy as an active technique through which teachers can influence the performance of their students. The result is consistent with a study by (Kucher \& Kerren, 2015), who found that visual representation of information positively influences students' performance and helps increase their knowledge of a particular subject.

\subsection{Points missing from teacher preparation programs}

This study also attempted to analyze the challenges that come across by novice teachers while applying their knowledge and skills in their teaching profession. The qualitative interview data reported a variety of opinions concerning the problems they had met, and half the participants had experienced the challenge of differentiation, or in other words, the ability of teachers to identify the differences between the students and to fulfill the needs of each student (Coubergs, Struyven, Vanthournout, \& Engels, 2017). The responses also indicated that this challenge is mainly due to a lack of focus on differentiation techniques in teaching preparation programs. According to Coubergs, Struyven, Vanthournout, \& Engels (2017), the increasing diversity of the student body is raising some severe difficulties for teachers, who often find it difficult completely to understand a student's attitude in terms of their concerns, needs, and ways of thinking. Understanding a student's position ultimately defines the performance of the teacher. Therefore, the findings of this study and the findings of the previous literature suggest that different approaches require more attention in teacher preparation programs.

The responses of the interviewees also highlighted that a lack of experience and ability to cope with different situations is another critical challenge faced by most of the novice teachers. In this context, the outcomes highlighted an instance in which a respondent faced difficulties in dealing with three-year-old children, as they require a different style of teaching. Similarly, the style and approach of teaching are highly subject to different situations and factors, which implies that teachers are responsible for being adaptable for being able to change their teaching styles as per the requirements (Collie \& Martin, 2016). Based on our 
findings, it can, therefore, be stated that teacher preparation programs must place more emphasis on providing training on how to cope with a variety of situations while maintaining the highest level of teaching.

Further, this study divided the novice teachers into two groups: very beginner teachers with less than one year of experience and teachers with one to three years of experience. Neither the quantitative nor the qualitative outcomes revealed differences between these groups. Even the identified difficulties were more individualized as opposed to being associated with a specific group. Furthermore, the findings of this study on the challenges faced by teachers are also consistent with the findings of the previous literature, implying there is a significant need to address all of these problems to maintain the competencies of teachers.

\subsection{Contribution of the study}

The results of this study have the following implications. First, the study contributes to the literature by bringing in novice teachers' perspectives on their teaching competencies as supported by their teacher preparation program. The study also identified a few of the problems that the novice teachers encounter that deserve attention from both teacher preparation programs and schools. Second, more efforts to bridge programs and schools are necessary to prepare teachers in their early careers better.

Since this study highlighted the significance of training in the field of education for both novice teachers and qualified teachers, it will help to enhance the educational system in Qatar. Skilled teachers will be able to refine their skills, while novice teachers will learn to implement many teaching practices. Moreover, different schools and colleges can enhance their teacher development practices by using the discussed teacher training in their institutional processes.

\subsection{Limitations and future research directions of the study}

Given the accessibility issues for the researcher, the study was limited to a sample size of ninety-five participants. The study was also limited to the geographical bounds of Qatar and Q University. The findings of the study, therefore, remain provisional and have a few limitations. First, the findings are mainly derived from teachers' views, which could be further validated through a comparison with other perspectives like mentors and colleagues from schools, instructors from the training program, and students. Second, the current study mainly focuses on novice teachers working in governmental schools in Qatar. Therefore, further studies may include novice teachers working in international schools, who usually graduated in other countries, and thus provide an additional perspective to examine the effect of teacher preparation programs in the current study. Third, the outcome of the study may be further enriched by and compared with other sources of data, such as classroom observations and narratives. For future studies, the sample size could be increased, while other methodological techniques could be adopted. 


\section{Conclusion}

In conclusion, this study provides conclusive evidence that teacher preparation programs have a positive impact on the preparation of novice teachers in terms of their acquisition of professional skills and their overall contribution towards student development. Furthermore, the participant teachers were able to develop students' learning capability during their teaching practice. This investigation also explores specific difficulties encountered by novice teachers in Qatar. Consequently, the research has practical implications for and contributes to Qatar's educational mechanism.

The participants selected had given diverse opinions regarding the impact of the development programs preparing them for the future. The novice teachers found the programs significantly growing them in their confidence and selfsufficiency to become strong teachers in practice. Moreover, the teachers were able to develop innovative skills to build the learning capability of the students in the future. The overall analysis confirms that teacher preparation programs are necessary to help novice teachers place firm grounds in the educational career. To formulate a strong study in the future, it is suggested the research be backed with valid methods to be used to analyze the impacts. The impact analysis was focused mainly on using the academic administrations and the teachers as participants to assess the worth of the preparation programs.

\section{References}

Abu-Tineh, A. M., \& Sadiq, H. M. (2018). Characteristics and models of effective professional development: the case of school teachers in Qatar. Professional Development in Education, 44(2), 311-322. https://doi.org/10.1080/19415257.2017.1306788

Adnot, M., Dee, T., Katz, V., \& Wyckoff, J. (2017). Teacher turnover, teacher quality, and student achievement in DCPS. Educational Evaluation and Policy Analysis, 39(1), 54-76. https://doi.org/10.3386/w21922

Ahmed, F. B. J. (2018). Challenges of the Knowledge Society: Exploring the Case of Qatar. Global Economic Observer, 6(1), 39-54. https://doi.org/10.1111/muwo.12080

Al-Kaabi, A. F. A., \& Hossain, S. (2018). The Effects of Collaborative Learning on Students' Achievements and Skills According to Their Learning Styles within an E-Learning Environment: Qatar University. In Academic Growth in Higher Education (pp. 88-101): Brill Sense. https://doi.org/10.1163/9789004389342_008

Alkharusi, H. (2011). Teachers' Classroom Assessment Skills: Influence Of Gender, Subject Area, Grade Level, Teaching Experience, and In-service Assessment Training. Journal of Turkish Science Education (TUSED), 8(2). author. $(2017,2018)$.

Azhar, M., \& Kayani, M. M. (2017). Study of the Impact of Training of Novice Teachers in the Context of Transformative Learning in Punjab, Pakistan. Advanced Education, 4(8), 84-91. https:// doi.org/10.20535/2410-8286.112533

Baecher, L. (2012). Feedback from the field: What novice preK-12 ESL teachers want to tell TESOL teacher educators. TESOL Quarterly, 46(3), 578-588. https://doi.org/10.1002/tesq.43

Bettini, E. A., Jones, N. D., Brownell, M. T., Conroy, M. A., \& Leite, W. L. (2018). Relationships between novice teachers' social resources and workload 
manageability. The Journal of Special Education, 52(2), 113-126. https://doi.org/10.1177/0022466918775432

Brackett, M. A., Mayer, J. D., \& Warner, R. M. (2004). Emotional intelligence and its relation to everyday behavior. Personality and Individual differences, 36(6), 13871402. https://doi.org/10.1016/s0191-8869(03)00236-8

Canrinus, E. T., Helms-Lorenz, M., Beijaard, D., Buitink, J., \& Hofman, A. (2012). Selfefficacy, job satisfaction, motivation, and commitment: Exploring the relationships between indicators of teachers' professional identity. European journal of psychology of education, 27(1), 115-132. https:// doi.org/10.1007/s10212011-0069-2

Chaaban, Y., \& Du, X. (2017). Novice teachers' job satisfaction and coping strategies: Overcoming contextual challenges at Qatari government schools. Teaching and Teacher Education, 67, 340-350. https:// doi.org/10.1016/j.tate.2017.07.002

Cochran-Smith, M. (2013). Introduction: The politics of policy in teacher education: International perspectives. Paper presented at the Educational Forum.

Cohen, L., Manion, L., \& Morrison, K. (2013). Action research. In Research methods in education (pp. 368-385): Routledge. https://doi.org/10.4324/9781315456539-22

Collie, R. J., \& Martin, A. J. (2016). Adaptability: An important capacity for effective teachers. Educational Practice and Theory, 38(1), 27-39. https://doi.org/10.7459/ept/38.1.03

Coubergs, C., Struyven, K., Vanthournout, G., \& Engels, N. (2017). Measuring teachers' perceptions about differentiated instruction: The DI-Quest instrument and model. Studies in Educational Evaluation, 53, 41-54. https://doi.org/10.1016/j.stueduc.2017.02.004

Council, S. E. (2007). Qatar National Professional Standards for Teachers and School Leaders. Doha, Qatar: Eduction Institute.

Creswell, J. W., \& Clark, V. L. P. (2017). Designing and conducting mixed methods research: Sage publications.

DeAngelis, K. J., Wall, A. F., \& Che, J. (2013). The impact of preservice preparation and early career support on novice teachers' career intentions and decisions. Journal of teacher education, 64(4), 338-355. https://doi.org/10.1177/0022487113488945

Ellili-Cherif, M., Romanowski, M. H., \& Nasser, R. (2012). All that glitters is not gold: Challenges of teacher and school leader licensure licensing system in Qatar. International Journal of Educational Development, 32(3), 471-481. https:// doi.org/10.1016/j.ijedudev.2011.11.010

Faez, F., \& Valeo, A. (2012). TESOL teacher education: Novice teachers' perceptions of their preparedness and efficacy in the classroom. TESOL Quarterly, 46(3), 450471. https://doi.org/10.1002/tesq.37

Fantilli, R. D., \& McDougall, D. E. (2009). A study of novice teachers: Challenges and supports in the first years. Teaching and teacher education, 25(6), 814-825. https://doi.org/10.1016/j.tate.2009.02.021

Friedman, I. A., \& Kass, E. (2002). Teacher self-efficacy: A classroom-organization conceptualization. Teaching and teacher education, 18(6), 675-686. https://doi.org/10.1016/s0742-051x(02)00027-6

Gavish, B., \& Friedman, I. A. (2010). Novice teachers' experience of teaching: A dynamic aspect of burnout. Social Psychology of Education, 13(2), 141-167. https://doi.org/10.1007/s11218-009-9108-0

Glennie, E. J., Mason, M., \& Edmunds, J. A. (2016). Retention and satisfaction of novice teachers: Lessons from a school reform model. Journal of Education and Training Studies, 4(4), 244-258. https://doi.org/10.11114/jets.v4i4.1458 
Goh, P. S. C., Yusuf, Q., \& Wong, K. T. (2017). Lived Experience: Perceptions of Competency of Novice Teachers. International Journal of Instruction, 10(1), 21-36.

Gold, Y. (1996). Beginning teacher support: Attrition, mentoring, and induction. Handbook of research on teacher education, 2, 548-594. https:// doi.org/10.12973/iji.2017.1012a

Goodwin, A. L., Smith, L., Souto-Manning, M., Cheruvu, R., Tan, M. Y., Reed, R., \& Taveras, L. (2014). What should teacher educators know and be able to do? Perspectives from practicing teacher educators. Journal of Teacher Education, 65(4), 284-302. https://doi.org/10.1177/0022487114535266

Holmes, B., Parker, D., \& Gibson, J. (2019). Rethinking Teacher Retention In Hard-ToStaff Schools. Contemporary Issues in Education Research (CIER), 12(1), 27-32. https://doi.org/10.19030/cier.v12i1.10260

Kang, H., \& Zinger, D. (2019). What do core practices offer in preparing novice science teachers for equitable instruction? Science Education, 103(4), 823-853.

Kucher, K., \& Kerren, A. (2015). Text visualization techniques: Taxonomy, visual survey, and community insights. Paper presented at the 2015 IEEE Pacific Visualization Symposium (PacificVis). https:/ / doi.org/10.1002/sce.21507

Kukla-Acevedo, S. (2008). Teacher effectiveness: The roles of teacher characteristics, preparation, and turnover.

Kvale, S., \& Brinkmann, S. (2009). Interviews: Learning the craft of qualitative interviewing. In: London: Sage. https:// doi.org/10.1080/09638180.2012.675165

Levski, D. (2003). The development of the sense of a failure among students of teaching. Unpublished seminar paper. Unpublished seminar paper.

Lopes, P. N., Grewal, D., Kadis, J., Gall, M., \& Salovey, P. (2006). Evidence that emotional intelligence is related to job performance and affect and attitudes at work. Psicothema, 18, 132-138.

McLean, L., Abry, T., Taylor, M., Jimenez, M., \& Granger, K. (2017). Teachers' mental health and perceptions of school climate across the transition from training to teaching. Teaching and Teacher Education, 65, 230-240.

Nasser, R., Cherif, M., \& Romanowski, M. (2011). Factors that impact student usage of the learning management system in Qatari schools. The International Review of Research in Open and Distributed Learning, 12(6), 39-62. https://doi.org/10.31357/fmscmst.2016.00242

Ödalen, J., Brommesson, D., Erlingsson, G. Ó., Schaffer, J. K., \& Fogelgren, M. (2019). Teaching university teachers to become better teachers: the effects of pedagogical training courses at six Swedish universities. Higher Education Research \& Development, 38(2), 339-353.

Rivkin, S. G., Hanushek, E. A., \& Kain, J. F. (2005). Teachers, schools, and academic achievement. Econometrica, 73(2), 417-458. https:// doi.org/10.1080/07294360.2018.1512955

Romanowski, M. H., Ellili-Cherif, M., Al Ammari, B., \& Al Attiya, A. (2013). Qatar's educational reform: The experiences and perceptions of principals, teachers, and parents. https://doi.org/10.5296/ije.v5i3.3995

Smith, T. M., \& Ingersoll, R. M. (2004). What are the effects of induction and mentoring on beginning teacher turnover? American educational research journal, 41(3), 681714. https://doi.org/10.3102/01623737026003681

Sutcher, L., Darling-Hammond, L., \& Carver-Thomas, D. (2016). A coming crisis in teaching? Teacher supply, demand, and shortages in the US. In: Palo Alto, CA: Learning Policy Institute.

Tait, M. (2008). Resilience as a contributor to novice teacher success, commitment, and retention. Teacher Education Quarterly, 35(4), 57-75. 
Truchot, D., \& Deregard, M. (2001). Perceived inequity, communal orientation, and burnout: The role of helping models. Work \& Stress, 15(4), 347-356. https://doi.org/10.1080/02678370110086380

Tschannen-Moran, M., \& Hoy, A. W. (2007). The differential antecedents of self-efficacy beliefs of novice and experienced teachers. Teaching and Teacher Education, 23(6), 944-956.

UNESCO. (2019). Sustainable Development Goals. https:// doi.org/10.1016/j.tate.2006.05.003

Veenman, S. (1984). Perceived problems of beginning teachers. Review of educational research, 54(2), 143-178. https:/ / doi.org/10.3102/00346543054002143

Youngs, P., Odden, A., \& Porter, A. C. (2003). State policy related to teacher licensure. Educational Policy, 17(2), 217-236. https://doi.org/10.1177/0895904803017002002

Zeichner, K. M., \& Tabachnick, B. R. (1981). Are the effects of university teacher education washed out' by school experience? Journal of teacher education, 32(3), 711.

Zins, J. E. (2004). Building academic success on social and emotional learning: What does the research say? : Teachers College Press. https://doi.org/10.1177/002248718103200302 